\title{
A Ligand-free, Soluble Urokinase Receptor Is Present in the Ascitic Fluid from Patients with Ovarian Cancer
}

\author{
Nina Pedersen, * Manfred Schmitt, ${ }^{\star}$ Ebbe Ronne, ${ }^{3}$ Maria Ines Nicoletti," Gunilla Hoyer-Hansen, ${ }^{5}$ Massimo Conese, ${ }^{\star}$ \\ Raffaella Giavazzi," Keld Dano, ${ }^{3}$ Walter Kuhn, ${ }^{\ddagger}$ Fritz Jänicke, ${ }^{\ddagger}$ and Francesco Blasi ${ }^{\star \Uparrow}$ \\ ${ }^{*}$ Institute of Microbiology, University of Copenhagen, 1353 Copenhagen, Denmark; ${ }^{\ddagger}$ Frauenklinik der Technischen Universität \\ München, 8000 München 80, Germany; ${ }^{\S}$ Finsen Laboratory, Rigshospital, 2100 Copenhagen, Denmark; \\ "'Mario Negri" Institute for Pharmacological Research, 24100 Bergamo; and 'Department of Genetics \\ and Microbial Biology, University of Milan, 20133 Milan, Italy
}

\begin{abstract}
We have identified a soluble form of the human urokinase plasminogen activator ( $\mathrm{UPA}$ ) receptor (UPAR) in the ascitic fluids from patients with ovarian cancer. After purification of UPAR from the ascitic fluids by ligand-affinity chromatography (prouPA Sepharose), the uPAR was initially identified by crosslinking to a radiolabeled amino-terminal fragment of human uPA. The uPAR purified from the ascitic fluid has no bound ligand ( $\mathrm{UPA}$ ), as similar amounts can be purified by ligand-affinity chromatography as by immuno-affinity chromatography. uPAR from ascitic fluids partitions in the water phase after a temperature-dependent phase separation of a detergent extract. It therefore lacks at least the lipid moiety of the glycophospholipid anchor present in cellular-bound uPARs. It is highly glycosylated and the deglycosylated form has the same electrophoretic mobility as previously characterized cellular uPAR from other sources. The immunoreactivity of the purified uPAR from the ascitic fluid is indistinguishable from that of characterized uPAR, demonstrated by Western blotting with three different anti-uPAR monoclonal antibodies. The uPAR was found in 11 of 11 ascitic fluids from patients with ovarian cancer and in elevated amounts in the plasma from 2 of 3 patients. The concentration of soluble uPAR in the ascitic fluid was estimated to range between 1 and $10 \mathrm{ng} / \mathrm{ml}$. Human soluble uPAR, derived from the tumor cells, was also found in the ascitic fluid and serum from nude mice xenografted intraperitoneally with three different human ovarian carcinomas. (J. Clin. Invest. 1993.92:2160-2167.) Key words: ovarian cancer • urokinase plasminogen activator receptor • ascitic fluid • plasma • soluble receptor
\end{abstract}

\section{Introduction}

Physiological and pathological invasive processes correlate with or depend on the activity of proteolytic enzymes, particularly plasminogen activators $(1,2)$. For some tumor cells the invasive and metastatic behavior in vivo and in vitro can be modulated by artificially modifying (i.e., increasing or decreas-

Address correspondence to Dr. Nina Pedersen, University Institute of Microbiology, Øster Farimagsgade 2A, 1353 Copenhagen K, Denmark. 1993.

Received for publication 22 June 1992 and in revised form 22 June

J. Clin. Invest.

(c) The American Society for Clinical Investigation, Inc.

$0021-9738 / 93 / 11 / 2160 / 08 \$ 2.00$

Volume 92, November 1993, 2160-2167 ing) the activity of the urokinase-type plasminogen activator (uPA $)^{1}$ of the cells (3-12). uPA is localized at the leading edge of experimental and human malignant tumors, of the implanting embryo, and of migrating macrophages (13-17).

Localization of the uPA activity to the cell surface of normal and neoplastic cells depends on the presence of a specific cell surface receptor for UPA (uPAR) (18), which can be located in some cultured cells at the cell-to-substratum and cellto-cell contacts $(19,20)$. uPAR is a $50-60-\mathrm{kD}$, single chain, highly glycosylated, and glycosyl phosphatidyl-inositol (GPI)anchored cell surface protein (21-23). Binding to cellular uPAR increases the rate of activation of pro-uPA at least 20fold both in vivo and in vitro $(24,25)$. Surface-associated uPA activity is controlled by uPAR through the selective internalization and degradation of $\mathrm{UPA} /$ inhibitor complexes, whereas active uPA and pro-uPA are not internalized by the receptor ( 16 , 26-28). Thus, uPAR plays an important role in regulating the surface activity of uPA and the cellular localization of active extracellular proteolysis. UPAR has also been suggested to transduce regulatory signals modifying the growth and the adhesive state of cells $(29,30)$. For all these reasons, UPAR is a central molecule in UPA-dependent biological functions as shown by direct complementation studies between UPA and uPAR $(25,31)$. Such complementation may occur by both paracrine and autocrine mechanisms in vitro and in human tumors $(17,32,33)$.

Compared with benign tumors, cancer tissues have been known to produce high levels of plasminogen activators, particularly uPA (reviewed in references 2 and 34). Recently, the measurement of the uPA content in primary breast cancer extracts has been demonstrated to be an independent, statistically significant, prognostic factor predictive for early relapse and overall survival (35-40). In many cultured cancer cells the level of UPAR is high and it can be further increased by tumor promoters and growth factors (41-43; L. R. Lund and K. Danø, unpublished results). Even more significantly, uPAR has been detected by in situ hybridization and immunohistochemistry in all analyzed cases of human colon, breast, and other solid human cancers ( 17, 44; C. Pyke and K. Danø, unpublished results). In ovarian tumors, the level of membranebound UPAR was found increased in malignant vs. benign tumors (45).

1. Abbreviations used in this paper: ATF, amino-terminal fragment of uPA; CHAPS, 3-[(3-cholamidopropyl) dimethyl-ammonio]-1-propanesulfonic acid; DSS, $N, N^{\prime}$-disuccinimidyl suberate; Endo $\mathrm{H}$, endoglycosidase H; GPI, glycosyl phosphatidyl-inositol; PIPLC, bacterial phosphatidyl inositol-specific phospholipase C; PNGase F, N-glycosidase F; s-uPAR, soluble uPA receptor; uPA, urokinase-type plasminogen activator; UPAR, UPA receptor. 
Circulating, soluble forms of cell surface receptors with ligand-binding properties have been described (46-52). The presence of a naturally occurring, circulating, soluble form of UPAR has been demonstrated in plasma from patients with paroxysmal nocturnal hemoglobinuria (53). These patients are deficient in synthesis or processing of GPI anchors, which is a characteristic of cell surface-bound UPAR. However, in the mouse an alternatively spliced mRNA, coding for a putative soluble form of UPAR, has been described (54). In this paper we demonstrate that a soluble, hydrophilic, and ligand-free form of UPAR is present in the ascitic fluid and plasma from patients with highly invasive ovarian carcinomas. We also demonstrate the presence of human UPAR in the ascitic fluid and serum of nude mice xenografted intraperitoneally with three different human ovarian carcinomas.

\section{Methods}

Materials. Highly purified recombinant pro-uPA expressed in Escherichia coli was kindly donated by Dr. Paolo Sarmientos (Farmitalia Carlo Erba, Milan, Italy). The amino-terminal fragment of uPA (ATF) was a kind gift of Dr. Jack Henkin (Abbott Laboratories, Chicago, IL). Hybridomas producing monoclonal antibodies to human uPAR (R2, R3, and R4) have been described previously (55). $N, N^{\prime}$ disuccinimidyl suberate (DSS) was from Pierce Chemical Co. (Rockford, IL), CnBr-activated Sepharose 4B and protein G-Sepharose 4 Fast Flow were from Pharmacia Fine Chemicals (Uppsala, Sweden), aprotinin was from Sigma Chemical Co. (St. Louis, MO), Triton $\mathrm{X}-114$ was from Fluka Chemie AG (Buchs, Switzerland), and $N$-glycosidase $F(P N G a s e ~ F)$ and endoglycosidase $H$ (Endo $H$ ) were from Boehringer Mannheim Biochemicals (Mannheim, Germany). Saos-2 cells were obtained from American Type Culture Collection (Rockville, MD). Vectastain peroxidase kit was from Vector Labs., Inc., (Burlingame, CA).

Cell lysates and conditioned medium. Human Saos-2, mouse LB6Cl. 19 expressing a recombinant, human uPAR (21) and PMA-stimulated human U937 cells were grown and lysates were made as previously described (23). The mouse LB6-Cl.4.19 cells producing a recombinant, soluble, secreted form of human uPAR (s-uPAR) were grown, and conditioned medium was collected as previously described (56).

Ascitic fluid and plasma preparation. The ascitic fluid or plasma from patients with ovarian cancer was cleared by centrifugation $(3,000$ $g$ for $10 \mathrm{~min}$ ) and stored at $-20^{\circ} \mathrm{C}$. The patients C.B. and E.H. belonged to clinical stage 1, patients H.S., M.F., G.K., E.W., M.W., and U.E. to stage 3, and patients K.S., M.M., J.F., and K.W. to stage 4. Some ascites preparations contained anticoagulants. Bacterial phosphatidyl-inositol-specific phospholipase C (PIPLC) treatment of the ascitic fluid was with $0.05 \mathrm{U} / \mathrm{ml}$ at $37^{\circ} \mathrm{C}$ for $12 \mathrm{~h}$.

Purification of $U P A R$ with pro- $u P A$ Sepharose or anti-uPAR monoclonal antibody Sepharose. Pro-uPA Sepharose was prepared by coupling highly purified recombinant pro-uPA to $\mathrm{CNBr}$-activated Sepharose $4 \mathrm{~B}$ ( $1 \mathrm{mg}$ pro-uPA $/ \mathrm{ml} \mathrm{CNBr-Sepharose)} \mathrm{according} \mathrm{to} \mathrm{the} \mathrm{proce-}$ dure recommended by Pharmacia Fine Chemicals. Thawed ascitic fluid or plasma samples were cleared at $3,000 \mathrm{~g}$ for $10 \mathrm{~min}$, 3[(3-cholamidopropyl) dimethyl-ammonio]-1-propanesulfonic acid (CHAPS) was added to a final concentration of $0.1 \%$, and aprotinin to 0.3 trypsin inhibitor units (TIU) $/ \mathrm{ml}$. The samples were incubated overnight at $4^{\circ} \mathrm{C}$ with pro-uPA Sepharose $(50 \mu \mathrm{l}$ resin $/ \mathrm{ml}$ of ascitic fluid or plasma). The resin was washed twice in $1 \mathrm{ml}$ PBS containing $0.1 \%$ CHAPS and once in $1 \mathrm{ml} 10 \mathrm{mM}$ Na-phosphate buffer, $\mathrm{pH} 7.4$, containing $1 \mathrm{M} \mathrm{NaCl}$. The uPAR was eluted at room temperature with $200 \mu \mathrm{l} 0.1 \mathrm{M}$ acetic acid, $0.5 \mathrm{M} \mathrm{NaCl}, 0.1 \%$ CHAPS, pH 2.6, and either neutralized with Trizma base or precipitated with 3 vol of acetone overnight at $-20^{\circ} \mathrm{C}$ with $20 \mu \mathrm{g}$ cytochrome $\mathrm{C}$ as carrier.

uPAR was alternatively purified on anti-uPAR monoclonal antibody $R 2$ (55) coupled to protein G-Sepharose $(0.5 \mathrm{mg} / \mathrm{ml}$ protein
G-Sepharose) as described above, except that the samples were preincubated with protein G-Sepharose $\left(2 \mathrm{~h}\right.$ at $\left.4^{\circ} \mathrm{C}\right)$ and the supernatant was used for further purification (E. Rønne, unpublished results).

Detergent phase separation. Ascites or plasma samples were brought to $0.1 \mathrm{M}$ Tris- $\mathrm{HCl}, \mathrm{pH} 8.1,10 \mathrm{mM}$ EDTA, and $1 \%$ (wt/vol) Triton X-114 on ice. Temperature-dependent phase separation was carried out as described previously (23) and uPAR was purified from the two phases with pro-uPA Sepharose as described above.

Crosslinking of UPAR to ${ }^{125}$ I-ATF. ATF was iodinated with Iodogen to a specific activity of $10-15 \mathrm{mCi}^{125} \mathrm{I} / \mathrm{mg}$. ATF-containing amino acids $1-135$ or $1-143$ were used in different experiments. Eluates from pro-uPA Sepharose corresponding to $0.5 \mathrm{ml}$ ascitic fluid or plasma (unless otherwise stated) were added to $50,000 \mathrm{cpm}$ of ${ }^{125} \mathrm{I}$-ATF at $4{ }^{\circ} \mathrm{C}$ for 1-3 $\mathrm{h}$ in the presence or absence of $100 \mathrm{nM}$ unlabeled uPA or pro-uPA as competitor to assess binding specificity. The samples were subsequently crosslinked with DSS and analyzed by $12.5 \%$ acrylamide SDS-PAGE and autoradiography as previously described (23).

Deglycosylation of $u P A R$ crosslinked to ${ }^{125} I-A T F$. Removal of Nbound carbohydrates was performed on crosslinked ${ }^{125} \mathrm{I}-\mathrm{ATF} / \mathrm{UPAR}$ complexes. Treatment with PNGase F was performed as described (23), except the incubation was for $5 \mathrm{~h}$. Samples treated with Endo $\mathrm{H}$ were adjusted to include $0.2 \%$ SDS and $50 \mathrm{mM}$ sodium citrate, $\mathrm{pH} 5.5$. Endo $\mathrm{H}(0.1 \mathrm{U} / \mathrm{ml})$ was added and the samples were incubated at $37^{\circ} \mathrm{C}$ for $4 \mathrm{~h}$.

Immunoblotting. uPAR from $8 \mathrm{ml}$ ascitic fluid was purified on pro-uPA Sepharose, acetone precipitated, and dissolved in SDS-PAGE sample buffer without $\beta$-mercaptoethanol (57). $350 \mu$ l LB6-Cl.4.19 medium containing s-uPAR was acetone precipitated and dissolved in the same sample buffer. The samples were separated by $12.5 \%$ acrylamide SDS-PAGE and blotted onto nitrocellulose membranes, the blots blocked in PBS containing 2\% low-fat dry milk, and incubated with monoclonal anti-uPAR antibodies ( R1, R2, R3, and R4 [23], each at $\sim 0.3 \mu \mathrm{g} / \mathrm{ml}$, either as a mixture or separately). The filters were washed and developed using the Vectastain peroxidase kit.

Intraperitoneal xenografting of human ovarian carcinoma cell lines into nude mice. Female NCr- $n u / n u$ mice were obtained from the animal production colony of the National Cancer Institute-Frederick Cancer Research and Development Center (Frederick, MD) and used when 8-10 wk old. Throughout this study nude mice were housed in air-filtered laminar-flow cabinets and manipulated according to aseptical procedures. HOC8 cells were derived from pleural effusion, and $\mathrm{HOC} 10$ and $\mathrm{HOC} 22$ were from ascites of patients with ovarian carcinoma. The HOC lines were established and maintained as ascites in nude mice as described previously $(58,59) .10^{7}$ cells of the HOC cell lines were injected as a suspension intraperitoneally in nude mice. Blood and ascites were collected $30 \mathrm{~d}$ later (two mice per cell line). Blood was obtained by intracardiac puncture from anesthesized mice and the serum collected after centrifugation at $3,000 \mathrm{rpm}$ for $10 \mathrm{~min}$. Mice were killed and ascites harvested with $3 \mathrm{ml}$ of $0.9 \% \mathrm{NaCl}$ and centrifuged at $1,200 \mathrm{rpm}$ for $10 \mathrm{~min}$. Serum and peritoneal lavage were obtained from non-tumor-bearing animals and processed in the same way. Serum and ascitic fluid were stored at $-80^{\circ} \mathrm{C}$ until analysis. UPAR from serum and ascitic fluid $(100 \mu \mathrm{l})$ was purified on pro-uPA Sepharose and crosslinked to ${ }^{125} \mathrm{I}-\mathrm{ATF}$ as described above.

\section{Results}

A $u P A$ binding protein can be detected in the ascitic fluid from patients with ovarian cancer. We have used a sensitive ${ }^{125}$ I-ATF crosslinking assay (see Methods) to test for the presence of a soluble form of UPAR in the ascitic fluid and plasma from patients with diagnosed ovarian carcinomas. The assay is sensitive (lower range of sensitivity is $0.5 \mathrm{ng} / \mathrm{ml}$ ) and specific for human, ligand-free uPAR (60). However, after initial attempts, it became clear that due to the high amount of protein in the fluids, the signal obtained was of insufficient intensity to allow an unequivocal recognition of the presence of UPAR 


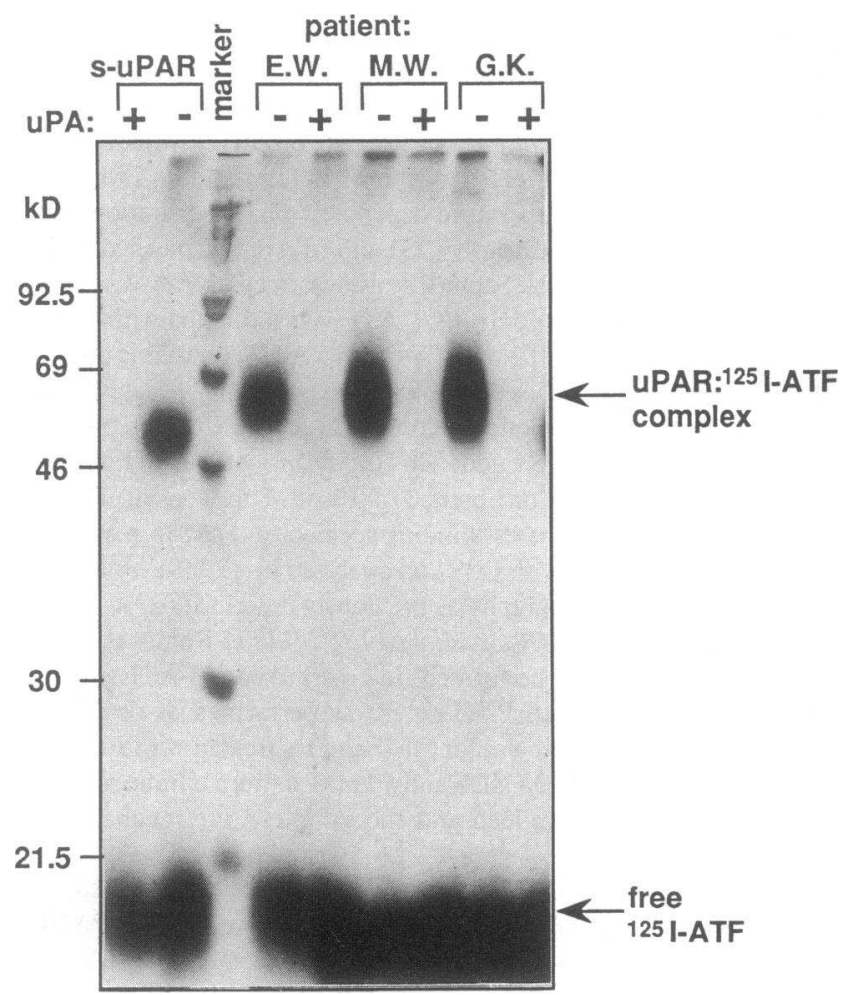

Figure 1. The ascitic fluid from ovarian cancer patients contains a protein that can be crosslinked to ${ }^{125}$ I-ATF. Pro-uPA Sepharose eluate of ascitic fluid from three patients (E.W., M.W., and G.K.) was chemically crosslinked with DSS to ${ }^{125}$ I-ATF and run on SDS-PAGE and visualized by autoradiography. (+) Presence or ( - ) absence of unlabeled uPA competitor ( $100 \mathrm{nM}$ ) during the crosslinking. s-uPAR is a recombinant, soluble form of human uPAR secreted by a mouse cell line (LB6-Cl.4.19) included as control.

(data not shown). Therefore, we had to use a simple purification step, in which samples were incubated with human prouPA Sepharose or anti-human uPAR monoclonal antibody Sepharose. The bound material was eluted with acidic buffer and the eluates were tested for UPAR activity by crosslinking to ${ }^{125}$ I-ATF and SDS-PAGE (see Methods). Fig. 1 shows the electrophoretic analysis of the eluate from $1.5 \mathrm{ml}$ of ascitic fluid of three patients after pro-uPA Sepharose purification. In all cases, a ${ }^{125} \mathrm{I}-\mathrm{ATF}$ binding protein was detected. The binding was specific, as $100 \mathrm{nM}$ unlabeled uPA (Fig. 1) and recombinant pro-uPA (not shown) could compete for binding to ${ }^{125} \mathrm{I}$ ATF. Clearing the ascitic fluid by centrifugation at $150.000 \mathrm{~g}$ for $2 \mathrm{~h}$ before the purification on pro-uPA Sepharose did not reduce the amount of ${ }^{125} \mathrm{I}$-ATF binding protein (data not shown). For comparison, the crosslinking of ${ }^{125}$ I-ATF to a recombinant, truncated, soluble human uPAR (s-uPAR) expressed by a mouse cell line (LB6-Cl.4.19) is shown (Fig. 1).

The $U P A$ binding protein from the ascitic fluids has the same apparent molecular mass as UPAR and can be deglycosylated in a similar manner. We next compared the electrophoretic mobility of the uPA binding protein purified on pro-uPA Sepharose from ascitic fluid with that of UPAR present in extracts from PMA-stimulated monocyte-like U937 cells, the osteosarcoma cell line Saos-2, or with s-uPAR. As shown in Fig. 2 , the crosslinked ${ }^{125} \mathrm{I}$-ATF-binding complex from the ascitic fluid of patient M.W. migrated as a broad heterogeneous band with a molecular mass of $\sim 60-70 \mathrm{kD}$, similar to that of human ${ }^{125}$ I-ATF/ uPAR complex of Saos- 2 cells and U937 cells (65-80 kD), but slightly larger than that formed by s-uPAR (50-55 kD), consistent with the uPARs being $\sim 50-70 \mathrm{kD}$ $(23,56,61)$. All the previously described uPARs are highly glycosylated. Deglycosylation with PNGase F reduces the apparent molecular mass of the ${ }^{125} \mathrm{I}-\mathrm{ATF} / \mathrm{UPAR}$ complex of U937 cells, Saos- 2 cells, and s-uPAR to $\sim 45 \mathrm{kD}$ (23), identical to the apparent molecular mass of the PNGase F-treated ${ }^{125} \mathrm{I}$-ATF/complex with the uPA binding protein purified from the ascitic fluid from patient M.W. (Fig. 2). PNGase F treatment gave the same result for uPA binding protein purified from ascitic fluids from three other patients (G.K., E.W., and K.G.) (data not shown). The sensitivity to PNGase F shows that the glycosylation is of the complex type. As is the case for cell surface-associated UPAR, the UPA binding protein from the ascitic fluid is insensitive to Endo $H(62)$ (Fig. 2).

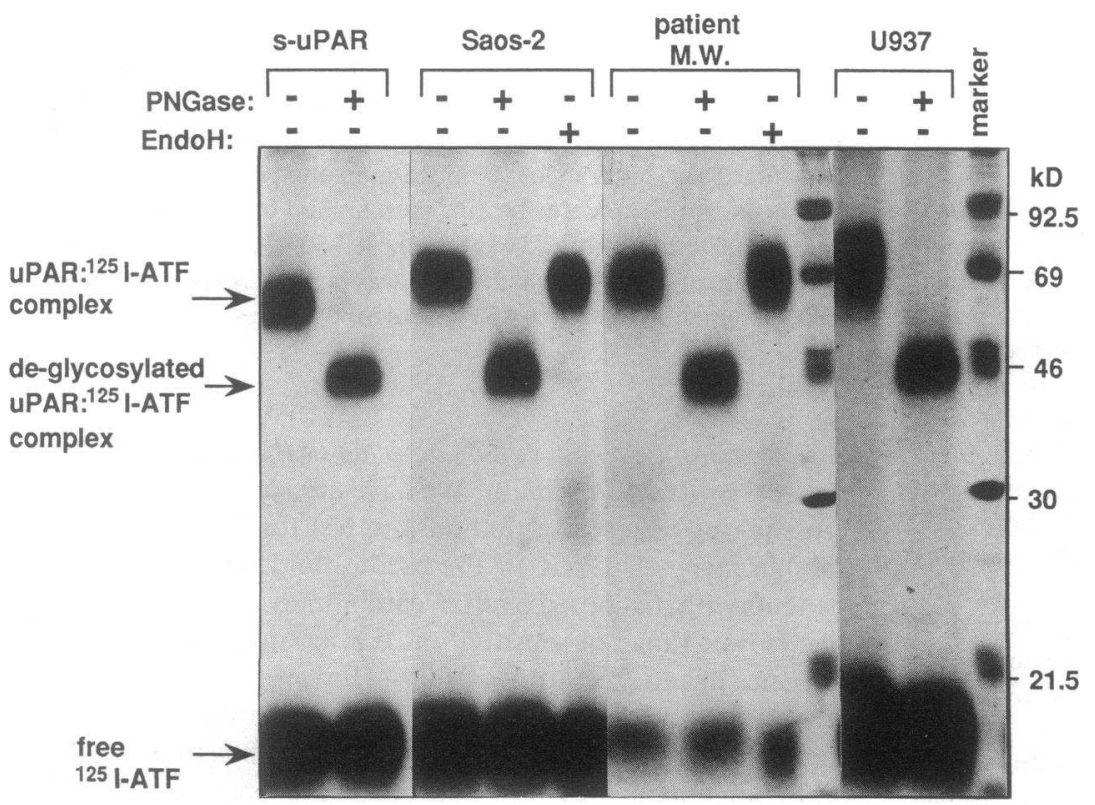

Figure 2. Comparison of apparent molecular mass of UPAR from the ascitic fluid from ovarian cancer patients and UPAR from human cell lines with and without deglycosylation. Electrophoretic mobility of the ${ }^{125}$ I-ATF-binding protein from the pro-uPA Sepharose eluate (from patient M.W.) after crosslinking and deglycosylation in SDSPAGE and autoradiography. ${ }^{125}$ I-ATF crosslinked to uPAR from cell lysates of PMA-stimulated U937 cells, Saos- 2 cells, and conditioned medium from LB6-Cl.4.19 containing s-uPAR are included as controls. Deglycosylation was performed as shown above each lane with either PNGase F or Endo $\mathrm{H}$. 
The uPA binding protein has the same immunoreactivity as $u P A R$. We next tested whether the soluble uPA binding protein was immunologically related to uPAR. We first used a mixture of four different monoclonal antibodies (R1, R2, R3, and R4) raised against the UPAR purified from the PMA-stimulated U937 cells. These antibodies were previously shown to recognize either the amino- or the carboxy-terminal moieties of uPAR (55). The uPA binding protein was purified from ascitic fluid from three patients and subjected to nonreducing SDSPAGE and immunoblotted with the mixture of R1, R2, R3, and R4 monoclonal antibodies (Fig. 3). A positive reaction with the antibodies was observed for all three patients, showing a band migrating at $45-50 \mathrm{kD}$. As a positive control, s-uPAR from LB6-Cl.4.19 medium was immunoblotted in the same way, showing a band of $\sim 45 \mathrm{kD}$. Both molecular masses are consistent with those determined by crosslinking to ATF. The uPA binding protein purified from the ascitic fluid of patient E.W. was tested with each of the four antibodies separately and they all gave a positive reaction (data not shown). Thus, the ascitic fluid of ovarian cancer patients contains an uPA binding protein immunologically related to uPAR, suggesting that this molecule is at least highly homologeous, if not identical, to the previously described membrane-bound uPAR.

UPAR from the ascitic fluid is water soluble. The uPAR so far, analyzed from cells of human, mouse, and rat origin, is a cell surface protein attached to the plasma membrane through a GPI anchor (22, 63-65). We therefore tested whether uPAR from the ascitic fluid had properties compatible with a GPI-anchored protein. UPAR in Triton X-114 cell lysates partitions with the detergent phase upon a temperature-dependent phase

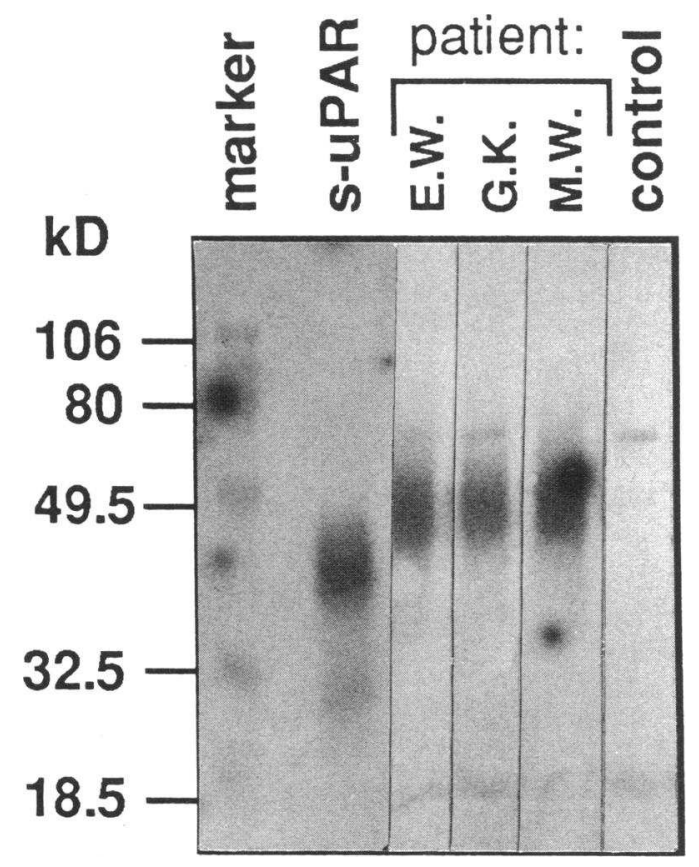

Figure 3. The ascitic fluid from ovarian cancer patients contains a protein that is recognized by monoclonal antibodies raised against uPAR from human U937 cells. The pro-uPA Sepharose eluate of 8 $\mathrm{ml}$ ascitic fluid from three patients (as indicated) was run on nonreducing SDS-PAGE, transferred to nitrocellulose, and immunoblotted using a mixture of the anti-uPAR monoclonal antibodies $(\mathrm{R} 1, \mathrm{R} 2$, $\mathrm{R} 3$, and R4). Positive control is the acetone-precipitated medium from s-uPAR-producing LB6-Cl.4.19 cells, and negative control is the eluate from a mock pro-uPA Sepharose purification. separation (23). Removal of the lipid moiety of the uPAR from U937 or LB6-Cl.19 cells by PIPLC, however, causes uPAR to partition with the water phase (22). The same watersoluble behavior is observed with recombinant uPAR mutants lacking the GPI anchor or when the wild-type protein is expressed in a GPI-deficient cell line $(56,64)$. To test whether the uPAR from ascitic fluid was in a membrane-bound form (e.g., in shedded vesicles), we used the same approach. LB6-Cl.19 cells $(\mathrm{Cl} .19)$ expressing the wild-type GPI-anchored uPAR were used as control. As shown in Fig. 4 by crosslinking with ${ }^{125}$ I-ATF, only the detergent phase (lanes $D$ ) of LB6-Cl.19 Triton X-114 lysate contains uPAR. Freezing and thawing the cells before detergent lysis did not change the partitioning (not shown). We therefore subjected the ascitic fluid to Triton $\mathrm{X}-114$ treatment and phase separation. The water and detergent phases were incubated with pro-uPA Sepharose and the eluates crosslinked to ${ }^{125}$ I-ATF. uPAR from the ascitic fluid was detected only in the water phase (lanes $W$ ). Pretreatment of the ascitic fluid with PIPLC made no difference in partitioning. Fig. 4 shows uPAR purified from the ascitic fluid of patient M.W., but identical results were obtained with ascitic fluid from three other patients (G.K., E.W., and K.G.).

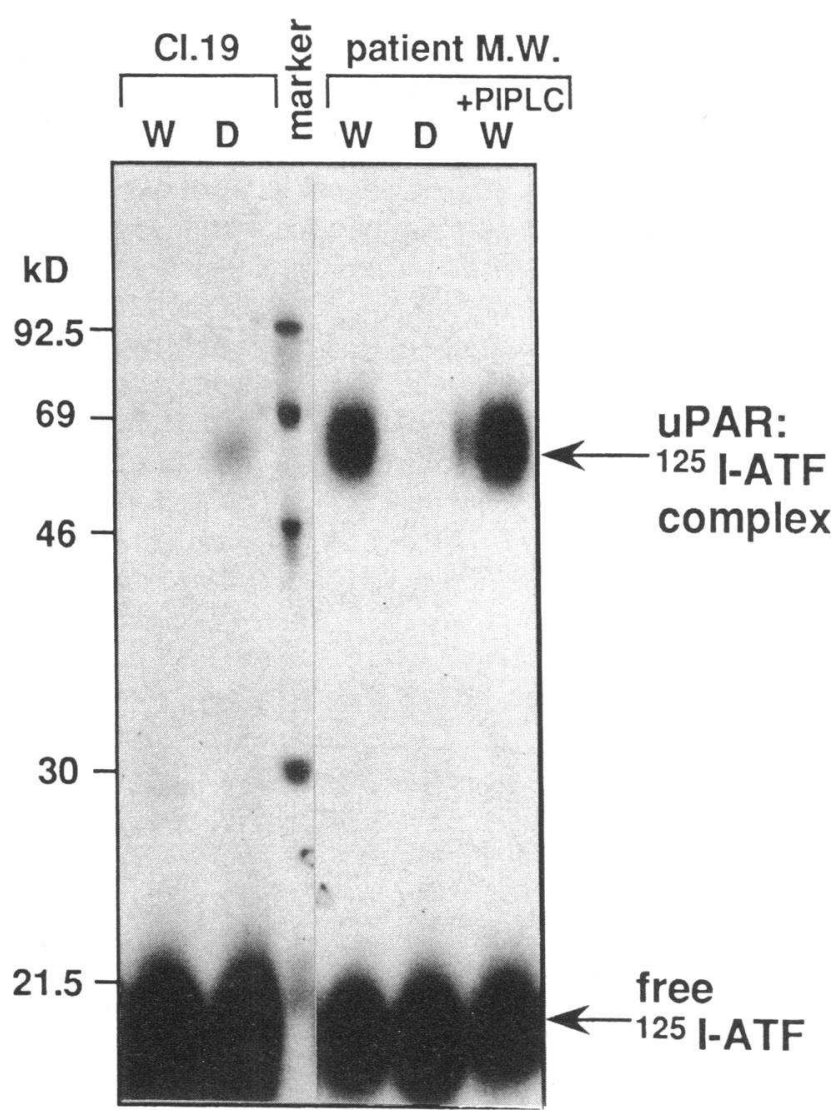

Figure 4. The uPAR in ascitic fluid from ovarian cancer patients is in a water-soluble form. A Triton X-114 temperature-dependent phase partitioning of the ascitic fluid of patient M.W. was performed. uPAR from the water and detergent phases was purified on pro-uPA Sepharose and crosslinked to ${ }^{125}$ I-ATF and run on SDS-PAGE and autoradiography. ( $W$ and $D)$ Water and the Detergent phases, respectively. $(+P I P L C)$ Sample was treated with PIPLC before the phase separation. As control, a Triton X-114 lysate of LB6-Cl.19 cells (Cl.19), which express the GPI-anchored uPAR, was phase separated and each phase was crosslinked to ${ }^{125} \mathrm{I}$-ATF as above. 
As all samples in this experiment were cleared by centrifugation at $3,000 \mathrm{~g}$ before any treatment, the uPAR cannot be cell bound. Centrifugation of the ascitic fluids at $150.000 \mathrm{~g}$ before purification gave no loss of uPAR, indicating that the uPAR is not associated with membrane debris. We also verified that the presence of anticoagulants, or the freeze-thawing procedure to which the ascitic fluids had been subjected, did not affect the phase partitioning of uPAR expressed in LB6-Cl.19 cells (data not shown). We conclude, therefore, that the ascitic fluid of ovarian cancer patients contains a water-soluble form of uPAR missing the lipid moiety of the GPI anchor.

$U P A R$ is present in all analyzed ascitic fluids from patients with ovarian cancer. We have extended this study and analyzed ascitic fluid from a total of 11 patients with ovarian cancer for the presence of the soluble uPAR. Fig. 5 shows the ${ }^{125} \mathrm{I}$-ATF crosslinked uPAR purified from ascitic fluid using immuno-affinity chromatography (R2-protein G-Sepharose). Identical results were obtained using ligand-affinity chromatography (pro-uPA Sepharose). Ligand-bound uPAR retains its ligand during the purification with pro-uPA Sepharose and cannot be detected by crosslinking to ${ }^{125}$ I-ATF (data not shown). In all cases, we detected uPAR with the same electrophoretic migration (all from $0.5 \mathrm{ml}$ of ascitic fluid). Elevated amounts of soluble uPAR (purified from $0.5 \mathrm{ml}$ plasma on R2-protein G-Sepharose) was also detected in the plasma of two of three ovarian cancer patients as compared with plasma from a healthy person. In the case shown, the level of uPAR from plasma of a healthy person is higher than previously found using pro-uPA Sepharose for purification (data not shown, and reference 53). uPAR from the plasma also partitioned into the water phase in detergent phase separation (not shown).

We have quantitated the amount of soluble uPAR in the ascitic fluid from three patients (G.K., E.W., and M.W.) by an ELISA for uPAR (E. Rønne et al., unpublished results) using pro-uPA Sepharose purified uPAR from the ascitic fluid, compared with a known amount of s-uPAR purified in the same manner. The level of uPAR in these samples range from 2.5 to $3.5 \mathrm{ng} / \mathrm{ml}$ (data not shown). Mixing a known amount of purified s-uPAR to the ascitic fluid before the purification gave an additive value. By comparing the relative amounts of crosslinked uPAR from the different patients and a known amount of s-uPAR, we estimate the concentration of uPAR in the ascitic fluids to range from 1 to $10 \mathrm{ng} / \mathrm{ml}$, and in the plasma (patients J.F. and K.W.) to be in the order of $0.05 \mathrm{ng} / \mathrm{ml}$, while that of the control plasma was $\sim 0.01 \mathrm{ng} / \mathrm{ml}$.

Ascitic fluid and serum from nude mice bearing human ovarian tumor xenografts contains soluble, human UPAR. In the case of the human patients, it was not possible to determine the source of the soluble uPAR in the ascitic fluids. It could derive from the tumors themselves, but could also derive from macrophages or other cells in the peritoneum. To determine the possibility that the soluble uPAR is derived from the tumor cells, we tested three human ovarian carcinoma xenografts transplanted intraperitoneally into nude mice. The carcinoma cell lines grow in the peritoneal cavity of nude mice and all produce ascites. Histopathological characteristics of the patients' primary tumor were maintained in nude mice (59). At $30 \mathrm{~d}$ after transplant, HOC8 and HOC22 caused massive invasion of the peritoneal organs, while only microscopic tumor deposits were observed in mice bearing HOC10.

Serum and ascitic fluid was collected from tumor-bearing mice. $100 \mu \mathrm{l}$ of each sample was purified on pro-uPA Sepharose and analyzed by crosslinking to ${ }^{125}$ I-ATF in exactly the same manner as from human patients (Fig. 6). Human ${ }^{125}$ IATF cannot be crosslinked to the mouse uPAR (65). Therefore, the crosslinked products can only be attributed to human uPAR present in the mouse samples. As expected, there is no crosslinkable uPAR in the serum or ascitic fluid of control tumor-free mice. However, there is detectable uPAR in the ascitic fluid of HOC10-xenografted mice and even higher amounts with HOC22- and HOC8-xenografted mice. In the serum, UPAR is undetectable with mice xenografted with HOC 10 , but clearly detectable with HOC22 and HOC8. The size of the ${ }^{125} \mathrm{I}$-ATF/uPAR complex is $70-80 \mathrm{kD}$ for all the complexes, which is the same size as for uPAR from other cells, and the formation is competed by $100 \mathrm{nM}$ unlabeled uPA. Duplicate mice in each experiment gave comparable results (not shown). The uPAR from the ascitic fluid of the mice

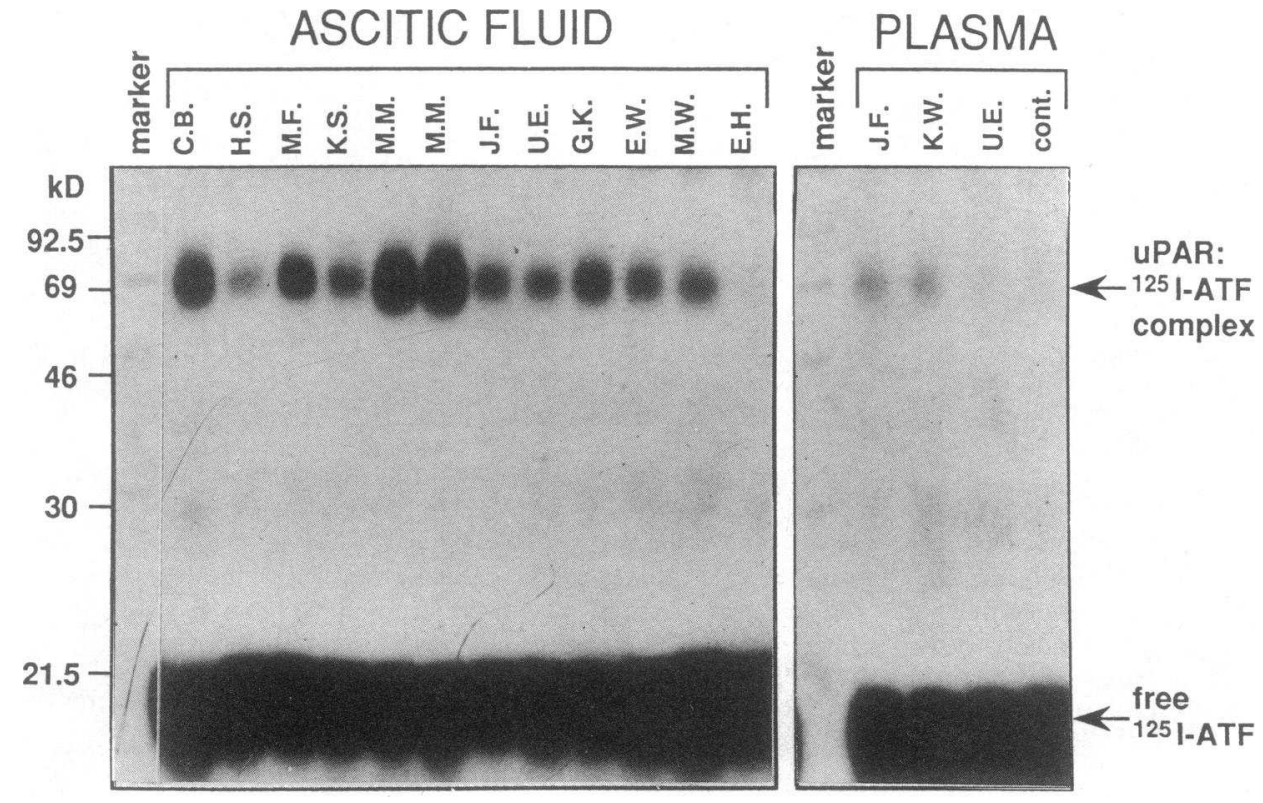

Figure 5. UPAR is present in the ascitic fluid and plasma from different patients with ovarian cancer. uPAR from ascitic fluid or plasma $(0.5 \mathrm{ml})$ from different patients, as indicated by initials, was purified by anti-uPAR immuno-affinity chromatography. The eluates were crosslinked to ${ }^{125}$ I-ATF and analyzed by SDS-PAGE and autoradiography. Plasma from a healthy volunteer treated in the same manner was included (cont.). 


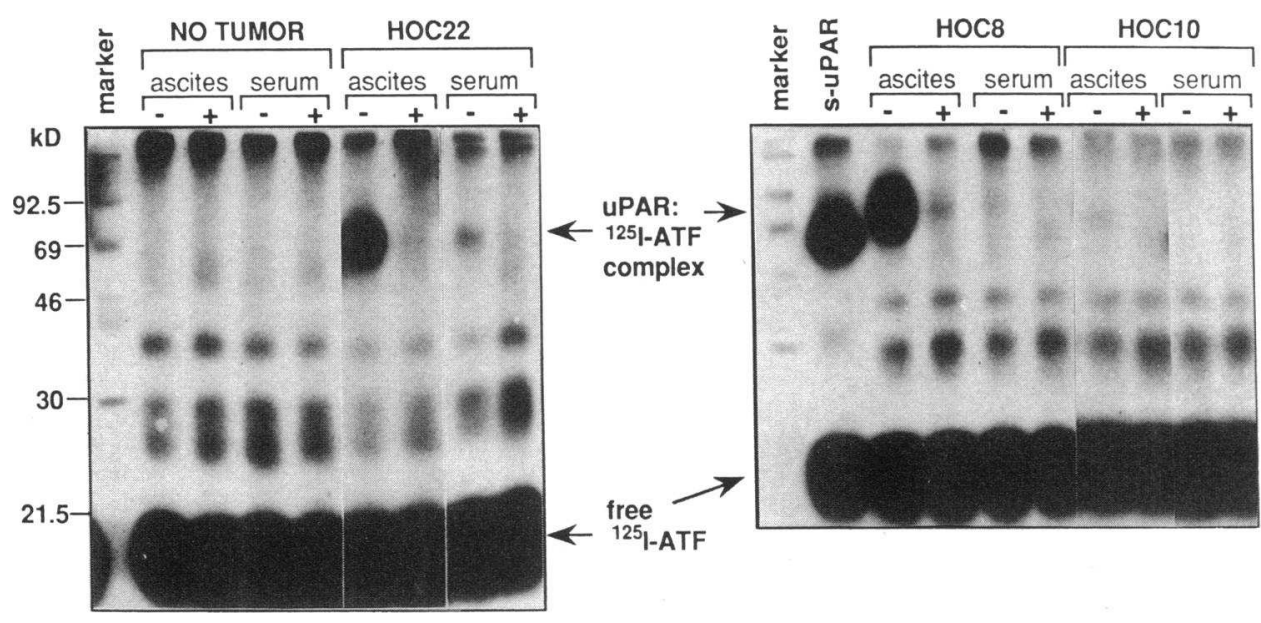

Figure 6. Ascitic fluid and serum from nude mice xenografted intraperitoneally with human ovarian carcinoma cell lines contain human s-uPAR. Nude mice were injected intraperitoneally with $10^{7}$ cells of the human ovarian carcinoma cell lines (HOC8, $\mathrm{HOC1}$, or $\mathrm{HOC} 22$ ). The mice were killed $30 \mathrm{~d}$ after tumor cell injection, and blood and ascitic fluid were harvested from each mouse. uPAR from the fluids was purified on pro-uPA Sepharose, crosslinked to ${ }^{125} \mathrm{I}-\mathrm{ATF}$, and analyzed by SDS-PAGE and autoradiography. Ascitic fluid and blood from non-tumor-bearing control mice were collected and analyzed in the same manner. $(+)$ Presence or $(-)$ absence of $100 \mathrm{nM}$ unlabeled uPA as competitor during the crosslinking. partitioned into the water phase (not shown), as is the case of UPAR in the ascitic fluid of ovarian cancer patients.

\section{Discussion}

The main finding of this report is the detection of a water-soluble form of UPAR in ascitic fluid and plasma of ovarian cancer patients. The uPAR was identified functionally by its ability to bind ${ }^{125} \mathrm{I}-\mathrm{ATF}$, uPA, and pro-uPA: structurally by its apparent molecular mass with and without deglycosylation treatment, and immunologically by the reactivity with four different antiuPAR monoclonal antibodies recognizing different epitopes of the uPAR molecule. The results leave no doubt as to its identification. uPAR from ascitic fluid appears to be different from the previously described cell-bound UPAR, as it is water soluble and not anchored to a cell surface. Solubilization (52) may result from the action of cellular or extracellular phospholipases or proteases on cell-surface bound uPAR present either on the tumor cells or on other cells (e.g., macrophages) in the peritoneum, as both PIPLC and the endoproteinase Asp-N produce water-soluble uPARs (22). Both ovarian tumors and macrophages have a high expression of surface-associated $\operatorname{uPAR}(18,45)$. It is not likely, however, that the soluble uPAR derives from cell lysis (in the peritoneum or during preparation) as centrifugation at $150,000 \mathrm{~g}$, which should remove membrane debris, does not remove the uPAR activity. In addition, membrane-bound uPAR from freeze/thawed cells retain their GPI anchor and thereby their detergent solubility.

However, the possibility that a small region of the UPAR is missing as a result of alternative splicing cannot be eliminated. The ascitic fluid uPAR is recognized by the monoclonal antibody R 3 and binds the ligand. Since both recognition sites are located at the amino terminus $(55,66)$, one would expect any structural differences, if present, to be most likely localized at the carboxy terminus, which contains the GPI attachment signal (22). However, the uPAR is also recognized by the monoclonal antibodies $\mathrm{R} 2$ and $\mathrm{R} 4$, which recognize a region different from the amino terminus (55). In fact, cDNA coding for a possibly soluble form of uPAR and arising as a result of alternative splicing of uPAR mRNA has been isolated from a mouse
cDNA library, although the protein itself has not yet been detected (54). The cDNA sequence shows that this form should contain the amino-terminal, ligand-binding part of the membrane-attached uPAR, but is missing the carboxy-terminal portion, including the GPI attachment and signal regions, which are replaced by a nonhydrophobic sequence. The putative product of this mRNA has not been observed yet, but is expected to have ligand-binding properties and to be secreted in a water-soluble form. The possibility exists, therefore, that the s-uPAR from the ovarian cancer ascitic fluids represents the product of a similar alternative splicing. It appears more likely, however, that ascitic fluid uPAR is the result of a protease- or phospholipase-mediated shedding of cellular receptor. This question can best be solved by the determination of the amino acid composition of uPAR from ascitic fluid. The presence of human UPAR in the ascitic fluid and plasma from nude mice xenografted with human ovarian carcinomas shows that, at least in this experimental system, the human s-uPAR derives from the tumor cells, as these are the only human cells in the mouse. Although the amount of uPAR present on the carcinomas used in this experiment have not yet been determined before xenografting, uPAR has previously been shown to be increased in malignant vs. benign ovarian tumors (45) and to be present in ovarian carcinoma cell lines $(67,68)$. And, indeed, the occurrence of soluble receptor was higher in the ascitic fluid and serum from mice bearing the more invasive xenografts (HOC22 and HOC8).

The plasma concentration of uPA is in the order of $\sim 1 \mathrm{nM}$ $(69,70)$, close to the dissociation constant for uPA/uPAR interaction (18). Therefore, ligand-bound uPAR may also be present in the ascitic fluid or plasma of ovarian carcinoma patients or in the plasma of healthy volunteers. This could account for the higher amount of uPAR detected in the plasma from a healthy person, when the UPAR was purified on R2 antibody Sepharose compared with pro-uPA Sepharose. The apparent accumulation of UPAR in the plasma of some patients, and in the nude mice injected with human tumors, indicates that the s-uPAR has a rather long half-life. If this is the case, s-uPAR in the plasma could contribute to increase the half-life of circulating pro-uPA. Although an increase in uPA 
production has been determined for patients with ovarian cancer, the increase was mostly observed in the tumor and cystic liquid, and not in the ascitic fluid (68). This is in agreement with our finding that the majority of the UPAR in the ascitic fluid is not associated with UPA, as the amounts of uPAR purified by R2 antibody and pro-uPA Sepharose were not significantly different. In conclusion, we have shown that a s-uPAR circulates in biological fluids of ovarian cancer patients and that a simple procedure can be used for its quantitation in plasma, serum, and ascitic fluid. The data presented in this paper suggest that the presence of UPAR may be related to the malignant phenotype and that the UPAR found in the ascitic fluid and plasma may derive from the tumors. The observation that human ovarian tumor cell lines produce high amounts of human s-uPAR in the ascitic fluid and serum of nude mice provides a model system that will help to identify the mechanism causing the accumulation of s-uPAR. Also, this model system can be used to investigate a possible correlation between the amount of s-uPAR and the progression of the tumor growth and malignancy. To establish whether the presence of s-uPAR in biological fluids can be used as a parameter for the diagnosis or prognosis of the disease, a higher number of patients (including other groups of patients) is needed.

\section{Acknowledgments}

We are grateful to Dr. Jack Henkin (Abbott Labs.) for ATF, Dr. Paolo Sarmientos for pro-uPA, and Dr. Maria Luisa Nolli for uPA. We thank John Post from the Finsen Laboratory for excellent photographic work.

This work was supported by grants of the Danish Cancer Society, the Danish Biotechnology Program, the Consiglio Nazionale delle Ricerche (PF ACRO), the Associazione Italiana Ricerche sul Cancro, and the Deutsche Forshungsgemeinshaft (GR 280/4-1).

\section{References}

1. Reich, E. 1978. Activation of plasminogen: a general mechanism for producing localized extracellular proteolysis. In Molecular Basis of Biological Degradative Processes. R. D. Berlin, H. Herrmann, I. H. Lepow, and J. M. Tanzer, editors. Academic Press, New York. 155-164.

2. Danø, K., P. A. Andreasen, J. Grøndahl-Hansen, P. Kristensen, L. S. Nielsen, and L. Skriver. 1985. Plasminogen activators, tissue degradation, and cancer. Adv. Cancer Res. 44:139-266.

3. Ossowski, L., and E. Reich. 1983. Antibodies to plasminogen activator inhibit human tumor metastasis. Cell. 35:611-619.

4. Hearing, V. J., L. W. Law, A. Corti, E. Appella, and F. Blasi. 1988. Modulation of metastatic potential by cell surface urokinase of murine cells. Cancer Res. 48:1270-1278.

5. Ossowski, L. 1988. In vivo invasion of modified chorioallantoic membrane by tumor cells: the role of cell surface bound urokinase. J. Cell Biol. 107:24372445 .

6. Axelrod, J. H., R. Reich, and R. Miskin. 1989. Expression of human recombinant plasminogen activators enhances invasion and experimental metastasis of H-ras-transformed NIH 3T3 cells. Mol. Cell. Biol. 9:2133-2141.

7. Reich, R., E. W. Thompson, Y. Iwamoto, G. W. Martin, J. R. Deason, G. C. Fuller, and R. Miskin. 1988. Effect of inhibitors of plasminogen activator, serine proteases and collagenase IV on the invasion of basement membranes by metastatic cells. Cancer Res. 48:3307-3312.

8. Cajot, J.-F., W.-D. Schleuning, R. L. Medcalf, J. Bamat, J. Testuz, L. Liebermann, and B. Sordat. 1989. Mouse L cells expressing prourokinase-type plasminogen activator: effects on extracellular matrix degradation and invasion. J. Cell Biol. 109:915-925.

9. Cajot, J.-F., J. Bamat, G. E. Bergonzelli, E. K. Kruithof, R. L. Medcalf, J. Testuz, and B. Sordat. 1990. Plasminogen activator inhibitor type 1 is a potent natural inhibitor of extracellular matrix degradation by fibrosarcoma and colon carcinoma cells. Proc. Natl. Acad. Sci. USA. 87:6939-6943.

10. Schlechte, W., G. Murano, and D. Boyd. 1989. Examination of the role of the urokinase receptor in human colon cancer mediated laminin degradation. Cancer Res. 49:6064-6069.

11. Cohen, R. L., X.-P. Xi, C. W. Crowley, B. K. Lucas, A. D. Levinson, and
M. A. Shuman. 1991. Effects of urokinase receptor occupancy on plasmin generation and proteolysis of basement membrane by human tumor cells. Blood. 78:479-487.

12. Ossowski, L., H. Russo-Payne, and E. L. Wilson. 1991. Inhibition of urokinase-type plasminogen activator by antibodies: the effect on dissemination of a human tumor in the nude mouse. Cancer Res. 51:274-281.

13. Grøndahl-Hansen, J., E. Ralf kiær, L. T. Kirkeby, P. Kristensen, L. R. Lund, and K. Danø. 1991. Localization of urokinase-type plasminogen activator in stromal cells in adenocarcinomas of the colon in humans. Am. J. Pathol. 138:111-117.

14. Sappino, A.-P., J. Huarte, D. Belin, and J.-D. Vassalli. 1989. Plasminogen activators in tissue remodeling and invasion: $\mathrm{mRNA}$ localization in mouse ovaries and implanting embryos. J. Cell Biol. 109:2471-2479.

15. Skriver, L., L.-I. Larsson, V. Kielberg, L. S. Nielsen, P. A. Andresen, P. Kristensen, and K. Danø. 1984. Immunocytochemical localization of urokinasetype plasminogen activator in Lewis lung carcinoma. J. Cell Biol. 99:753-758.

16. Estreicher, A., J. Muhlhauser, J.-L. Carpentier, L. Orci, and J.-D. Vassalli. 1990. The receptor for urokinase type plasminogen activator polarizes expression of the protease to the leading edge of migrating monocytes and promotes degradation of enzyme inhibitor complexes. J. Cell Biol. 111:783-792.

17. Pyke, C., P. Kristensen, E. Ralf kjær, J. Grøndahl-Hansen, J. Eriksen, F. Blasi, and K. Danø. 1991. Urokinase-type plasminogen activator is expressed in stromal cells and its receptor in cancer cells at invasive foci in human colon adenocarcinomas. Am. J. Pathol. 138:1059-1067.

18. Blasi, F. 1988. Surface receptors for urokinase plasminogen activator. Fibrinolysis. 2:73-84.

19. Pöllänen, J., K. Hedman, L. S. Nielsen, K. Danø, and A. Vaheri. 1988. Ultrastructural localization of plasma-membrane associated urokinase type plasminogen activator at focal contacts. J. Cell Biol. 106:87-95.

20. Hebert, C. A., and J. B. Baker. 1988. Linkage of extracellular plasminogen activator to the fibroblast cytoskeleton: colocalization of cell surface urokinase with vinculin. J. Cell Biol. 106:1241-1247.

21. Roldan, A. L., M.-V. Cubellis, M. T. Masucci, N. Behrendt, L. R. Lund, K. Danø, E. Appella, and F. Blasi. 1990. Cloning and expression of the receptor for human urokinase plasminogen activator, a central molecule in cell-surface, plasmin-dependent proteolysis. EMBO (Eur. Mol. Biol. Organ.) J. 9:467-474.

22. Ploug, M., E. Rønne, N. Behrendt, A. L. Jensen, F. Blasi, and K. Danø. 1991. Cellular receptor for urokinase plasminogen activator: carboxy terminal processing and membrane anchoring by glycosyl-phosphatidylinositol. J. Biol. Chem. 266:1926-1933.

23. Behrendt, N., E. Rønne, M. Ploug, T. Petri, D. Løber, L. S. Nielsen, W.-D. Schleuning, F. Blasi, E. Appella, and K. Danø. 1990. The human receptor for urokinase plasminogen activator. $\mathrm{NH}_{2}$ terminal amino acid sequence and glycosylation variants. J. Biol. Chem. 265:6453-6460.

24. Ellis, V., M. F. Scully, and V. V. Kakkar. 1989. Plasminogen activation initiated by single chain urokinase-type plasminogen activator: potentiation by U937 monocytes. J. Biol. Chem. 264:2185-2188.

25. Quax, P. H. A., N. Pedersen, M. T. Masucci, E. J. D. Weening-Verhoeff, K. Danø, J. H. Verheijen, and F. Blasi. 1991. Complementation of urokinaseproducing and receptor-producing cells in extracellular matrix degradation. Cell Regul. 2:793-803.

26. Cubellis, M. V., T.-C. Wun, and F. Blasi. 1990. Receptor-mediated internalization and degradation of urokinase is caused by its specific inhibitor PAI-1. EMBO (Eur. Mol. Biol. Organ.) J. 9:1079-1085.

27. Jensen, P. H., E. I. Christensen, P. Ebbesen, J. Gilemann, and P. A. Andreasen. 1990. Lysosomal degradation of receptor-bound urokinase-type plasminogen activator is enhanced by its inhibitors in human trophoblastic choriocarcinoma cells. Cell Regul. 1:1043-1056.

28. Olson, D., J. Pöllänen, G. Høyer-Hansen, E. Rønne, K. Sakaguchi, T.-C. Wun, E. Apella, K. Danø, and F. Blasi. 1992. Internalization of the urokinaseplasminogen activator inhibitor type-1 complex is mediated by the urokinase receptor. J. Biol. Chem. 267:9129-9133.

29. Rabbani, S. A., J. Desjardins, A. W. Bell, D. Benville, A. Mazar, J. Henkin, and D. Coltzman. 1990. An amino terminal fragment of urokinase isolated from a prostate cancer cell line (PC-3) is mitogenic for osteoclast.-like cells. Biochem. Biophys. Res. Commun. 173:1058-1064.

30. Nusrat, A. R., and H. A. Chapman. 1991. An autocrine role for urokinase in phorbol-ester mediated differentiation of myeloid cell lines. J. Clin. Invest. 87:1091-1097.

31. Ossowski, L., G. Clunie, M. T. Masucci, and F. Blasi. 1991. In vivo paracrine interaction between urokinase and its receptor: effect on tumor cell invasion. J. Cell Biol. 115:1107-1112.

32. Stoppelli, M. P., C. Tacchetti, M. V. Cubellis, A. Corti, V. J. Hearing, G. Cassani, E. Appella, and F. Blasi. 1986. Autocrine saturation of pro-urokinase receptors on human A431 cells. Cell. 45:675-684.

33. Hollas, W., F. Blasi, and D. Boyd. 1991. Role of urokinase receptor in facilitating extracellular matrix invasion by cultured colon cancer. Cancer Res. 51:3690-3695.

34. Schmitt, M., F. Jänicke, and H. Graeff. 1992. Tumor-associated proteases. Fibrinolysis. 6(Suppl. 4):3-26. 
35. Graeff, H., N. Harbeck, L. Pache, O. Wilhelm, F. Jänicke, and M. Schmitt. 1992. Prognostic impact and clinical relevance of tumor-associated proteases in breast cancer. Fibrinolysis. 6(Suppl. 4):45-53.

36. Foekens, J. A., M. Schmitt, W. L. J. van Putten, H. A. Peters, M. Bontenbal, F. Jänicke, and J. G. M. Klijn. 1992. Prognostic value of urokinase-type plasminogen activator in 671 primary breast cancer patients. Cancer Res. 52:6101-6105.

37. Jänicke, F., M. Schmitt, R. Hafter, A. Hollrieder, R. Babic, K. Ulm, W. Goessner, and H. Graeff. 1990. Urokinase-type plasminogen activator (u-PA) antigen is a predictor of early relapse in breast cancer. Fibrinolysis. 4:69-78.

38. Jänicke, F., M. Schmitt, L. Pache, K. Ulm, N. Harbeck, H. Höfler, and H. Graeff. 1993. Urokinase (uPA) and its inhibitor PAI-1 are strong and independent prognostic factors in node-negative breast cancer. Breast Cancer Res. Treat. 24:195-208.

39. Duffy, M. J., D. Reilly, C. O’Sullivan, N. O’Higgins, J. J. Fennelly, and P. Andreasen. 1990. Urokinase plasminogen activator, a new and independent prognostic marker in breast cancer. Cancer Res. 50:6827-6829.

40. Grøndahl-Hansen, J., I. J. Christensen, C. Rosenquist, N. Brünner, H. T. Mouridsen, K. Danø, and M. Blichert-Toft. 1993. High levels of urokinase-type plasminogen activator (UPA) and its inhibitor PAI-1 in cytosolic extracts of breast carcinomas are associated with poor prognosis. Cancer Res. 53:25132521.

41. Picone, R., E. L. Kajtaniak, L. S. Nielsen, N. Behrendt, M. R. Mastronicola, M.-V. Cubellis, M. P. Stoppelli, S. Pedersen, K. Danø, and F. Blasi. 1989. Regulation of urokinase receptors in monocyte-like U937 cells by phorbol ester phorbol myristate acetate. J. Cell Biol. 108:693-702.

42. Lund, L. R., J. Rømer, E. Rønne, V. Ellis, F. Blasi, and K. Danø. 1991. Urokinase receptor biosynthesis, mRNA level and gene transcription are increased by transforming growth factor- $\beta 1$ in human A549 lung carcinoma cells. EMBO (Eur. Mol. Biol. Organ.) J. 10:3399-3407.

43. Boyd, D. 1989. Examination of the effects of epidermal growth factor on the production of urokinase and the expression of the plasminogen activator receptor in a human colon cancer cell line. Cancer Res. 49:2427-2432.

44. Pyke, C., N. Græm, E. Ralf kiær, E. Rønne, G. Høyer-Hansen, N. Brünner, and K. Danø. 1993. The receptor for urokinase is present in tumor-associated macrophages in ductal breast carcinoma. Cancer Res. 53:1911-1915.

45. Casslén, B., B. Gustavsson, and B. Ảstedt. 1991. Cell membrane receptors for urokinase plasminogen activator are increased in malignant ovarian tumors. Eur. J. Cancer. 27:1445-1448.

46. Selkoe, D. J. 1990. Deciphering Alzheimer's disease: the amyloid precursor protein yields new clues. Science (Wash. DC). 248:1058-1060.

47. Huizinga, T. W. J., C. E. van der Schoot, C. Jost, R. Klaassen, M. Kleijer, A. E. G. von dem Borne, D. Roos, and P. A. T. Tetteroo. 1988. The PI-linked receptor FcIII is released on stimulation of neutrophils. Nature (Lond.). 333:667-669.

48. Gower, H. J., C. H. Barton, V. L. Elsom, J. Thompson, S. E. Moore, G. Dickson, and F. S. Walsh. 1988. Alternative splicing generates a secreted form of N-CAM in muscle and brain. Cell. 55:955-964.

49. Baumbach, W. R., D. L. Horner, and J. S. Logan. 1989. The growth hormone binding protein in rat serum is an alternatively spliced form of the rat growth hormone receptor. Genes \& Dev. 3:1199-1205.

50. Petch, L. A., J. Harris, V. W. Raymond, A. Blasband, D. C. Lee, and H. S Earp. 1990. A truncated, secreted form of the epidermal growth factor receptor is encoded by an alternatively spliced transcript in normal rat tissue. Mol. Cell. Biol. 10:2973-2982.

51. Shih, Y. J., R. D. Baynes, B. G. Hudson, C. H. Flowers, B. S. Skikne, and J. D. Cook. 1990. Serum transferrin receptor is a truncated form of tissue receptor. J. Biol. Chem. 265:19077-19081.

52. Ehlers, M. R. W., and J. F. Riordan. 1991. Membrane proteins with soluble counterparts: role of proteolysis in the release of transmembrane proteins. Biochemistry. 30:10065-10074.

53. Ploug, M., J. Eriksen, T. Plesner, N. E. Hansen, and K. Danø. 1992. A soluble form of the glycolipid-anchored receptor for urokinase-type plasminogen activator is secreted from peripheral blood leukocytes from patients with paroxysmal nocturnal hemoglobinuria. Eur. J. Biochem. 208:397-404.

54. Kristensen, P., J. Eriksen, F. Blasi, and K. Danø. 1991. Two alternatively spliced mouse urokinase receptor mRNAs with different histological localization in the gastrointestinal tract. J. Cell Biol. 115:1763-1771.

55. Rønne, E., N. Behrendt, V. Ellis, M. Ploug, K. Danø, and G. HøyerHansen. 1991. Cell-induced potentiation of the plasminogen activation system is abolished by a monoclonal antibody that recognizes the $\mathrm{NH}_{2}$-terminal domain of the urokinase receptor. FEBS (Fed. Eur. Biochem. Soc.) Lett. 288:233-236.

56. Masucci, M. T., N. Pedersen, and F. Blasi. 1991. A soluble, ligand binding mutant of the human urokinase plasminogen activator receptor. J. Biol. Chem. 266:8655-8658.

57. Laemmli, U. K. 1970. Cleavage of structural proteins during the assembly of the head of bacteriophage T4. Nature (Lond.). 227:680-685.

58. Massazza, G., A. Tomasoni, V. Lucchini, P. Allavena, E. Erba, N. Colombo, A. Mantovani, M. D'Incalci, C. Mangioni, and R. Giavazzi. 1989. Intraperitoneal and subcutaneous xenografts of human ovarian carcinoma in nude mice and their potential in experimental therapy. Int. J. Cancer. 44:494-500.

59. Masazza, G., V. Lucchini, A. Tomasoni, F. Peccatori, V. Lampasona, G Giudici, C. Mangioni, A. Biondi, and R. Giavazzi. 1991. Malignant behavior and resistance to cisplatin for human ovarian carcinoma xenografts established from the same patient at different stages of the disease. Cancer Res. 51:6358-6362.

60. Estreicher, A., A. Wohlwend, D. Belin, W.-D. Schleuning, and J.-D. Vassalli. 1989. Characterization of the cellular binding site for the urokinase-type plasminogen activator. J. Biol. Chem. 264:1180-1189.

61. Nielsen, L. S., G. M. Kellermann, N. Behrendt, R. Picone, K. Danø, and F. Blasi. 1988. A 55,000-60,000 Mr receptor protein for urokinase type plasminogen activator: identification in human tumor cell lines and partial purification. J. Biol. Chem. 263:2358-2363.

62. Møller, L. B., J. Pöllänen, E. Rønne, N. Pedersen, and F. Blasi. 1993. $\mathrm{N}$-linked glycosylation of the ligand-binding domain of the human urokinase receptor contributes to the affinity for its ligand. J. Biol. Chem. 268:1115211159 .

63. Ragno, P., S. Cassano, J. Degen, C. Kessler, F. Blasi, and G. Rossi. 1992. The receptor for the plasminogen activator of the urokinase type is up-regulated in transformed rat thyroid cells in culture. FEBS (Fed. Eur. Biochem. Soc.) Lett. 306:193-198.

64. Møller, L. B., M. Ploug, and F. Blasi. 1992. Structural requirements for glycosyl-phosphatidylinositol anchor attachment in the cellular receptor for urokinase plasminogen activator. Eur. J. Biochem. 308:493-500.

65. Solberg, H., D. Løber, J. Eriksen, M. Ploug, E. Rønne, N. Behrendt, K. Danø, and G. Høyer-Hansen. 1992. Identification and characterization of the murine cell surface receptor for the urokinase type plasminogen activator. Eur. $J$. Biochem. 205:451-458.

66. Behrendt, N., M. Ploug, L. Patthy, G. Houen, F. Blasi, and K. Danø. 1991. The ligand-binding domain of the cell surface receptor for urokinase-type plasminogen activator. J. Biol. Chem. 266:7842-7847.

67. Chucholowski, N., M. Schmitt, P. Rettenberger, E. Schüren, N. Moniwa, L. Goretzki, O. Wilhelm, U. Weidle, F. Jänicke, and H. Graeff. 1992. Flow cytometric analysis of the urokinase receptor ( UPAR) on tumor cells by fluorescent uPA ligands or monoclonal antibody \#3936. Fibrinolysis. 6(Suppl. 4):95102.

68. Casslén, B., and B. Astedt. 1992. The plasminogen activating system in ovarian carcinomas. Fibrinolysis. 6(Suppl. 4):65-69.

69. Grøndahl-Hansen, J., N. Agerlin, P. Munkholm-Larsen, L. S. Nielsen, and K. Danø. 1988. Sensitive and specific enzyme-linked immunosorbent assay for urokinase type plasminogen activator and its application to plasma from patients with breast cancer. J. Lab. Clin. Med. 111:42-51.

70. Schmitt, M., L. Goretzki, F. Jänicke, J. Calvete, M. Eulitz, H. Kobayashi, N. Chucholowski, and H. Graeff. 1991. Biological and clinical relevance of the urokinase-type plasminogen activator ( UPA) in breast cancer. Biomed. Biochim. Acta. 50:737-741. 